\title{
Literacy Toy for Enhancement Phonological Awareness: A Longitudinal Study
}

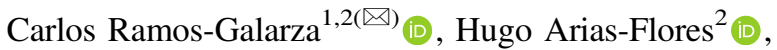 \\ Omar Cóndor-Herrera $^{2}$ (D), and Janio Jadán-Guerrero ${ }^{2}$ (D) \\ ${ }^{1}$ Facultad de Psicología, Pontificia Universidad Católica del Ecuador, \\ Av. 12 de Octubre y Roca, Quito, Ecuador \\ caramos@puce.edu.ec \\ 2 Centro de Investigación en Mecatrónica y Sistemas Interactivos MIST/Carrera \\ de Ingeniería en Ciencias de la Computación/Maestría en Educación mención \\ Innovación y Liderazgo Educativo/Carrera de Psicología/Carrera de \\ Administración, Universidad Tecnológica Indoamérica, \\ Av. Machala y Sabanilla, Quito, Ecuador \\ \{hugoarias, omarcondor, janiojadan\}@uti.edu.ec
}

\begin{abstract}
In this report it is presented the results of a longitudinal preexperimental study, it was realized a technological intervention to stimulate the phonological awareness through a tangible reading toy based on the RFID technology, consisting of a teddy bear and 30 letters in 3D from the Spanish alphabet. This study started with a sample of 200 children, from them, there were selected 17 children aged between 6 and 7 years $\left(M_{\text {age }}=6.47, S D=.51\right)$ with a phonological disorder from an educative institution. The procedure consisted of obtaining pre-test and post-test values with the Evaluation of Phonological Awareness (PECFO). Sampling inclusion criteria considered children presenting problems of phonemes' recognition and its relationship with graphemes. During 30 weeks it was realized an intervention with the technological toy and at the end of the sessions, it was applied the post-test. Results of phonological awareness showed statically significant differences among the pre $(M=12.88, S D=3.53)$ and post-test $(M=17.17, S D=2.96)$ this contributes to the empirical evidence of the intervened group improvement in this cognitive function $t_{(16)}=-3.67, p=.002$. From this research it is projected proposing technological innovations contributing in the treatment of children's cognitive difficulties.
\end{abstract}

Keywords: Phonological awareness $\cdot$ Literacy toy $\cdot$ Inclusive toys $\cdot$ RFID * PECFO

\section{Introduction}

Cognitive development is a central issue in the context of technological innovations for children's disorders treatment. Because of it, in this article, it is reported a longitudinal pre-experimental study, where it was realized an interactive device for children to improve their phonological development. Following, the benefits of technology usage in the treatment of cognitive difficulties are described, as well as the proposal of a 
reading tangible toy, as technological innovation, for the treatment of phonological awareness' difficulties. Afterward, it is explained the longitudinal pre-experimental study carried out.

\subsection{Benefits of Technological Usage for Cognitive Issues}

The use of ICT inserted in the educative field allows generating new forms of production, representation, diffusion and knowledge accessibility [1], which represents a constant innovation for education.

The use of a variety of devices and technological resources, adding modern students' innate abilities for using them, makes possible offering educative interactive innovations, different to those accustomed [2], which allows students to enjoy the learning process, generating on them an inner motivation, these emotions influence not just in motivation but improving significantly learning experience and academic achievements [3].

\subsection{Technological Devices Used in Phonological Awareness and Cognitive Difficulties}

Plenty studies are approaching technological usage to work on cognitive difficulties and phonological awareness, an example of it is the Project called Petit Ubinding, that has been designed by the University of Barcelona [4], which measured the impact of an educative method to stimulate reading in children belonging to the first grade of primary school, including on-line learning sessions. Another study conducted in a sample of deaf students about reading, orthography, and phonological abilities found that technological usage allows the improvement of these abilities [5]. On the other hand, the usage of computer-assisted pronunciation training (CAPT) is used in learning a second language for a variety range of age and technological use supports children identifying phonemes and bad-word pronouncing, suggesting to users the option to improve these errors [6]. There are other alphabetization programs based on the web offered possibilities, which have reported positive evidence improving phonological abilities that were worked on, such as phoneme-grapheme correspondence, segmentation of phonemes and word fluency [7].

Another field in this same research line is the usage of toys and inclusive games for children with disabilities rehabilitation, and in the same manner, these could be used in children presenting learning disorders such as dyslexia, dysgraphia, and dyslalia, reflecting excellent results in the learning process $[8,9]$. The previous investigation about the usage of web extension assisting reading and writing problems reported significant results of treating these issues, as well as increasing motivation and child's working frequency [10].

Implementing the usage of technological tools is substantive in children's initial reading process, as it is evidenced in the longitudinal study of early reading development through technological media. Intervened children with this type of stimulation improve the automatic integration of letters and sounds and a variety of measures that assess early reading and language abilities [20]. 


\subsection{The Necessity to Create a Friendly Device for Children with Cognitive Difficulties}

Children must be prepared to acquire abilities and knowledge in the actual world and the application of technology in the learning environment will allow them to use their thinking abilities to reach social and emotional development [11, 12]. Learning environments enriched with technology in its variety $[13,14]$ will improve attention levels, motivation, knowledge and students' abilities in a positive way, especially in children with language disorders and special education $[15,16]$.

\subsection{Technological Proposal to Work with Phonologic Awareness}

The proposal of a tangible reading toy is based on one of the already mentioned literature, in which it was developed a literacy kit called Kiteracy (Kit for Literacy) to generate interaction of children with Down's Syndrome in the learning process. The study realized was based on a qualitative technique, using recorded sessions in video with twelve children with Down's Syndrome belonging to an institute from Spain. This technological proposal is presented in three interactive ways: cardboard cards, a tablet and a technological radiofrequency (RFID) toy and tangible objects.

The task was conducted by special education teachers and 12 children presenting Down's Syndrome. There were design three experimental sessions with every child consisting of pair-work (professor-child). From these sessions, it was possible identifying that tangible interaction offers an enjoyable moment for children. Surveys and interviews' data collected from the information given by professors revealed that tangible objects offered higher adaptability to create reading pedagogic strategies [21].

Taking into consideration this experience and with positive results in the interaction, a new research question appeared, "It is possible to use the kit to stimulate phonological awareness in children with non-special conditions", to do it, it was necessary to make a kit's adaptation to Ecuadorian context, creating a kit called Kiteracy-PiFo (Fig. 1) based on the Picto-Phonic (PiFo) alphabetization methodology, which is composed by a teddy bear with an RFID lector incorporated and 30 labels representing alphabet's letters. There were manufactured 25 kits to conduct the preexperimental longitudinal study, to assess the effectiveness of interventions in children aged between 6 and 7 years [22].

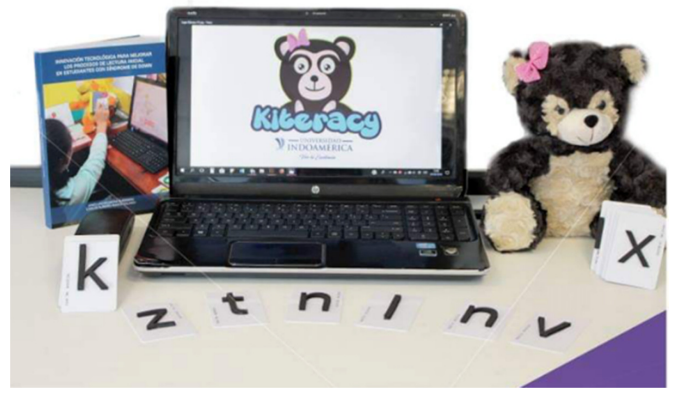

Fig. 1. Tangible reading toy Kiteracy-Pifo. 
The teddy bear contained cards RFID with the technical specification LANMU Smart ID Card Reader EM4099 USB - Proximity Sensor of $125 \mathrm{kHz}$. Also, there were used 30 cardboards made of plastic RFID with letters in pieces made of foaming material. The software allows the association between the card's coding and phonemes sound, the visualization of the grapheme and the interactive video of trace and vocalization.

\section{Method}

\subsection{Research Design}

There was applied a pre-experimental longitudinal study since it was worked with a group of students presenting alterations in the phonological awareness.

\subsection{Participants}

The sample started with 200 students, from them, 17 children aged between 6 and 7 years with phonological alterations were selected (Mage $=6.47, \mathrm{SD}=.51$ ). According to gender, $6(35.3 \%)$ were females and 11 (64.7\%) were males. These children belonged to the educative private system of Quito- Ecuador.

\subsection{Instruments}

For obtaining pre and post-test values, it was used the phonological awareness evaluation test (PECFO) [17], this test allows evaluating phonological awareness development in children.

\subsection{Procedure}

The pre-experimental longitudinal study was conducted in an educative institution. It started with the pre-test phonological awareness test. Afterward, it was realized a technological intervention with the device to improve phonological awareness for 30 weeks. Finally, in the post-test, the impact of this technological intervention was analyzed.

It is important to highlight that this research was approved by the Ethical Committee of Investigation with human beings of the University Indoamerica of Ecuador. Participant's representatives were asked to sign the informed consent of voluntary participation and children were asked to give their assent by signing in a form as well, of accepting being part of the study. Throughout this research ethical standards of investigation with human beings were followed, protecting participants' physical and psychological integrity at all times.

\subsection{Statistical Analysis}

Once the statistical hypotheses were proven, it was conducted a comparison of means with a T-test procedure for related samples between the pre and post-test realized. Also, there were applied statistical central tendency and dispersion measures to characterize the data. 


\section{Results}

In the beginning, descriptive values found were analyzed in the different measures. Table 1 shows these values.

Table 1. Descriptive results of the variables valued. Note: Mn (minimum), Mx (maximum), M (mean) and SD (Standard Deviation).

\begin{tabular}{l|r|l|l|l}
\hline Measure & \multicolumn{1}{|c|}{$M n$} & $M x$ & $M$ & $S D$ \\
\hline Pre-test & 4.00 & 18.00 & 12.88 & 3.53 \\
\hline Post-test & 11.00 & 23.00 & 17.17 & 2.96 \\
\hline
\end{tabular}

The second analysis realized was the comparison of means between the pre and post-test of the phonological awareness variable. Table 2 shows the results found.

Table 2. Comparison realized between the pre and post-test of the linguistical variable valued.

\begin{tabular}{l|l|l|l|l|l|l|l|l}
\hline & $M$ & $S D$ & $M n$ & $M x$ & $T$ & $D f$ & Sig. & $D$ \\
\hline Pre-test vs. Post-test & -4.29 & 4.82 & -6.77 & -1.82 & -3.67 & 16 & .002 & .68 \\
\hline
\end{tabular}

Figure 2 presents phonological awareness means' differences of pre and post-test.

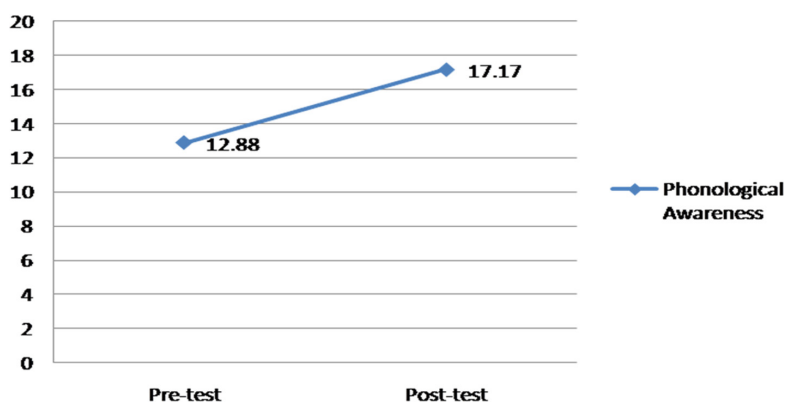

Fig. 2. Pre and post-test means differences.

\section{Conclusions}

This work reports an investigation that analyzed the impact of the technological development of Kiteracy-Pifo to intervene in the phonological awareness difficulties in children aged between 6 and 7 years.

Results found affirmed that its application has positive results since there were found statistically significant improvements in the phonological awareness between the pre and post-test. Results found in this investigation are concordant with the results found in previous research such as the one conducted by Thompson et al. [18] and Gilakjani and Rahimy [19], who have reported that technological use improves the oral phoneme-grapheme decoding precision as well as reading rating, contributing to significant improvement in pronunciation learning; this allows to affirm that children with 
learning difficulties will be benefited with reading, pronunciation, phonological awareness and writing abilities learning through technological use.

The future investigation that is proposed is related to the creation, production, and implementation of new technological inclusive devices contributing to the treatment of children with cognitive difficulties, as well as the implementation of these devices in usual educative contexts to stimulate cognitive processes.

Acknowledgments. The authors thank Universidad Tecnológica Indoamérica for funding this study through the project "Aplicación piloto del Kit Kiteracy para fortalecer el aprendizaje de lectura en niños y niñas de educación inicial" coordinated by Soledad Males and Ana Carolina Márquez.

\section{References}

1. de Pérez, A.M., Tellera, M.: Las TIC en la educación: nuevos ambientes de aprendizaje para la interacción educativa. Revista de Teoría y Didáctica de las Ciencias Sociales 18, 83-112 (2012)

2. Borba, M., Askar, P., Engelbrecht, J., Gadanidis, G., Llinares, S., Sanchéz, M.: Aprendizaje mixto, e-learning y aprendizaje móvil en la educación matemática. ZDM Math. Educ. 48, 589-610 (2016)

3. Anaya, A., Anaya, C.: "Motivar para aprobar o para aprender" estrategias de motivación del aprendizaje para los estudiantes. Tecnología Ciencia Educación 25(1), 5-14z (2010)

4. López, J., Pina, V., Ballesta, S., Bordoy, S., Pérez, L.: Proyecto petit Ubinding: método de adquisición y mejora de la lectura en primero de primaria. Estudio de eficacia, Revista de Logopedia, Foniatría y Audiología 40(1), 12-22 (2020)

5. Gonzáles, V., Domínguez, A.: Lectura, ortografía y habilidades fonológicas de estudiantes sordos con y sin implante coclear. Revista de Logopedia, Foniatría y Audiología 39(2), 7585 (2019)

6. Agarwal, C., Pinaki, C.: A review of tools and techniques for computer aided pronunciation training (CAPT) in english. Educ. Inf. Technol. 24, 3731-3743 (2019)

7. Mak, B., Cheung, A., Guo, X., Abrami, P., Wade, A.: Examining the impact of the ABRACADABRA (ABRA) web-based literacy program on primary school students in Hong Kong. Educ. Inf. Technol. 22, 2671-2691 (2017)

8. dos Santos Nunes, E.P., da Conceição Júnior, V.A., Giraldelli Santos, L.V., Pereira, M.F.L., de Faria Borges, L.C.L.: Inclusive toys for rehabilitation of children with disability: a systematic review. In: Antona, M., Stephanidis, C. (eds.) UAHCI 2017. LNCS, vol. 10277, pp. 503-514. Springer, Cham (2017). https://doi.org/10.1007/978-3-319-58706-6_41

9. El Kah, A., Lakhouaja, A.: Developing effective educative games for arabic children primarily dyslexics. Educ. Inf. Technol. 23, 2911-2930 (2018)

10. Pařilová, T.: DysHelper - the dyslexia assistive approach user study. In: Miesenberger, K., Kouroupetroglou, G. (eds.) ICCHP 2018. LNCS, vol. 10896, pp. 478-485. Springer, Cham (2018). https://doi.org/10.1007/978-3-319-94277-3_74

11. Ejikeme, A.N., Okpala, H.N.: Promoting children's learning through technology literacy: challenges to school librarians in the 21st century. Educ. Inf. Technol. 22(3), 1163-1177 (2017). https://doi.org/10.1007/s10639-016-9481-13

12. Adam, T., Tatnall, A.: The value of using ICT in the education of school students with learning difficulties. Educ. Inf. Technol. 22, 2711-2726 (2017). https://doi.org/10.1007/ s10639-017-9605-2 
13. Alghabban, W.G., Salama, R.M., Altalhi, A.H.: Mobile cloud computing: an effective multimodal interface tool for students with dyslexia. Comput. Hum. Behav. 75, 160-166 (2017)

14. Halloluwa, T., Vyas, D., Usoof, H., et al.: Gamification for development: a case of collaborative learning in Sri Lankan primary schools. Pers. Ubiquit. Comput. 22, 391-407 (2018). https://doi.org/10.1007/s00779-017-1073-6

15. Cakir, R., Korkmaz, O.: The effectiveness of augmented reality environments on individuals with special education needs. Educ. Inf. Technol. 24, 1631-1659 (2019). https://doi.org/10. 1007/s10639-018-9848-6

16. Khlaisang, J., Songkram, N.: Designing a virtual learning environment system for teaching 21st century skills to higher education students in ASEAN. Tech. Know. Learn. 24, 41-63 (2019). https://doi.org/10.1007/s10758-017-9310-7

17. Varela, V., De Barbieri, Z.: Prueba de evaluación de conciencia fonológica - PECFO (Phonological Awareness Assessment Test). Editorial BIOPSIQUE (2012)

18. Thompson, R., et al.: Effective instruction for persisting dyslexia in upper grades: adding hope stories and computer coding to explicit literacy instruction. Educ. Inf. Technol. 23, 1043-1068 (2018)

19. Gilakjani, A., Rahimy, R.: Factors influencing iranian teachers' use of computer assisted pronunciation teaching (CAPT). Educ. Inf. Technol. 24, 1715-1740 (2019)

20. Clayton, F., West, G., Sears, C., Hulme, C., Lervåg, A.: A longitudinal study of early reading development: letter-sound knowledge, phoneme awareness and RAN, but not lettersound integration, predict variations in reading development. Sci. Stud. Read. 24(2), 91-107 (2020). https://doi.org/10.1080/10888438.2019.1622546

21. Jadan-Guerrero, J., Jaen, J., Carpio, M.A., Guerrero, L.A.: Kiteracy: a kit of tangible objects to strengthen literacy skills in children with down syndrome. In: Proceedings of the 14th International Conference on Interaction Design and Children (IDC 2015), pp. 315-318. Association for Computing Machinery, New York (2015). https://doi.org/10.1145/2771839. 2771905

22. Jadán-Guerrero, J., Ramos-Galarza, C., de los Angeles Carpio-Brenes, M., Calle-Jimenez, T., Salvador-Ullauri, L., Nunes, I.L.: Phonological awareness intervention and basic literacy skill development with Kiteracy-PiFo. In: Nunes, I.L. (ed.) AHFE 2020. AISC, vol. 1207, pp. 319-325. Springer, Cham (2020). https://doi.org/10.1007/978-3-030-51369-6_43

Open Access This chapter is licensed under the terms of the Creative Commons Attribution 4.0 International License (http://creativecommons.org/licenses/by/4.0/), which permits use, sharing, adaptation, distribution and reproduction in any medium or format, as long as you give appropriate credit to the original author(s) and the source, provide a link to the Creative Commons license and indicate if changes were made.

The images or other third party material in this chapter are included in the chapter's Creative Commons license, unless indicated otherwise in a credit line to the material. If material is not included in the chapter's Creative Commons license and your intended use is not permitted by statutory regulation or exceeds the permitted use, you will need to obtain permission directly from the copyright holder.

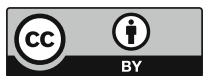

